\title{
Oral exposure of sulpiride promotes the proliferation of Brown-Norway rat prostates
}

\author{
CHENGCHENG ZHENG ${ }^{1-3}$, YONGWEI LUO ${ }^{1-3}$, YING CHEN $^{2,3}$, DINGSHI CHEN ${ }^{2,3}$, CONGCONG SHAO $^{2,3}$, \\ DONGYAN HUANG ${ }^{2,3}$, JING ZHU ${ }^{2,3}$, XIAOYAN MAO ${ }^{2,3}$, LEI LI ${ }^{2,3}$ and ZUYUE SUN ${ }^{1-3}$ \\ ${ }^{1}$ School of Pharmacy, Fudan University, Shanghai 200433; ${ }^{2}$ National Evaluation Centre for The Toxicology of \\ Fertility Regulating Drugs; ${ }^{3}$ National Population and Family Planning Key Laboratory of Contraceptive \\ Drugs and Devices, Shanghai Institute of Planned Parenthood Research, Shanghai 200032, P.R. China
}

Received October 10, 2017; Accepted February 22, 2018

DOI: $10.3892 /$ etm.2020.8521

\begin{abstract}
The aim of the present study was to establish an animal model of prostatic hyperplasia to explore the mechanisms of this disease. Sulpiride, a specific type 2 dopamine receptor antagonist, causes prostate toxicity by stimulating prolactin (PRL) production. Male Brown-Norway $(\mathrm{BN})$ rats were treated intragastrically (i.g.) with sulpiride (40 and $120 \mathrm{mg} / \mathrm{kg}$ daily) and vehicle (i.g., daily) for 4 weeks. The results demonstrated that sulpiride-treatment resulted in increased prostate size, prostate lobe weight, epithelial height and acinar luminal area. Furthermore, prostate lobe weight, epithelial height and acinar luminal area of lateral lobes (LP) significantly increased. These effects were dose dependent. Sulpiride treatment increased serum PRL, follicle-stimulating hormone and testosterone levels, while serum luteinizing hormone levels were reduced. Immunohistochemical analysis revealed that proliferating cell nuclear antigen and B-cell lymphoma-2 were significantly increased in certain sulpiride treated groups. Furthermore, estrogen receptor (ER)- $\alpha$ and androgen receptors were upregulated, while ER $\beta$ was downregulated in LP. The expression of stromal cell biomarkers, including vimentin, fibronectin and $\alpha$-smooth muscle actin were significantly increased in LP following $40 \mathrm{mg} / \mathrm{kg}$ sulpiride administration. These results suggest that sulpiride causes LP hyperplasia in $\mathrm{BN}$ rats by promoting proliferation and inhibiting prostate cell apoptosis via ER $\alpha$ and AR signaling.
\end{abstract}

\section{Introduction}

Benign prostatic hyperplasia $(\mathrm{BPH})$ is a hyper-proliferative disease that reduces the quality of life of elderly men. The

Correspondence to: Dr Zuyue Sun, National Evaluation Centre for The Toxicology of Fertility Regulating Drugs, Shanghai Institute of Planned Parenthood Research, 2140 Xie Tu Road, Xuhui, Shanghai 200032, P.R. China

E-mail: sunzy64@163.com

Key words: sulpiride, prolactin, biomarkers, estrogen receptor subtype, androgen receptor, prostatic hyperplasia worldwide incidence of $\mathrm{BPH}$ is $20 \%$ in men at age 40 , which rises to $70 \%$ by age 60 and $90 \%$ by age $90(1,2)$. BPH is characterized by a four-fold increase of stromal cells, which results in prostate gland expansion; therefore, it is generally considered a proliferative stromal disease $(3,4)$. BPH increases prostate size and tightens the urethra, producing symptoms in the lower urinary tract, including urinary intermittency, nocturia, frequency, dysuria, weak stream, incomplete emptying and suprapubic pain (5).

The pressures of modern society have led to the increased prevalence of mental health issues, which has prompted the production and use of various antipsychotic drugs (6). Antipsychotic drugs may cause toxic adverse effects, including menstrual disorder, amenorrhea, dysuria and constipation in the human reproductive system, particularly in the prostate (7), which has received increasing attention from clinicians.

Sulpiride, a specific type 2 dopamine receptor antagonist, produces various side effects, including insomnia, fatigue, tachycardia, liver dysfunction and delayed dyskinesia when the dose of sulpiride reaches $600 \mathrm{mg} /$ day (8-11). PRL is associated with the growth and development of BPH $(9,12,13)$. PRL levels increase, while testosterone (T) levels decrease with age, which indicates that PRL serves a key role in BPH development in the elderly $(8,14)$. Ahonen et al $(15)$ reported that PRL serves a primary role in the differentiation and proliferation of the prostate in rats and humans. The effects of PRL are mediated via signal transduction pathways triggered by PRL receptors (16). Słuczanowska-Głąbowska et al (9) revealed that PRL increases while $\mathrm{T}$ decreases in experimental rats that received metoclopramide. Morphological abnormalities were also observed in columnar epithelial cells of the lateral, dorsal and ventral lobes; however, prostate lobes did not exhibit morphological changes under hyperprolactinemia (7). Previous studies have indicated that PRL may promote prostate growth and cell proliferation synergistically with androgens $(8,17)$ Conversely, it has also been reported that PRL acts independently of $\mathrm{T}$ in prostate growth (18). Additional studies have revealed that PRL stimulates the secretion of prostate proteins and conversion of $\mathrm{T}$ to dihydrotestosterone $(19,20)$. The prostate is dependent on androgens, which serve a role in BPH (21). Furthermore, testosterone regulation, prostate structure and prostate function are influenced by tissue growth and the hypothalamus-pituitary-gonadal 
axis (22). T secretion is regulated by luteinizing hormone ( $\mathrm{LH})$ and follicle stimulating hormone (FSH) (23-27). Therefore, PRL may serve an important role in the regulation of prostate cell growth and differentiation.

Proliferating cell nuclear antigen (PCNA) mediates the proliferation of prostate cells in rats and, as such, is used as a marker of proliferation (28). In addition, B-cell lymphoma-2 $(\mathrm{Bcl}-2)$ is an anti-apoptotic protein that promotes prostate hyperplasia (29). Shi et al (30) revealed that estrogens contributed to the pathogenesis of BPH in elderly men. Estrogen receptor- $\alpha(E R \alpha)$ and estrogen receptor- $\beta(E R \beta)$ are expressed and are antagonistic; ER $\alpha$ mediates cell proliferation while ER $\beta$ regulates apoptosis $(31,32)$. Furthermore, the androgen receptor (AR) was demonstrated to promote prostate cells proliferation in BPH development (33). Similar to ERs, various co-regulators interact directly with AR, enhancing or reducing its transcriptional activity (34).

In $\mathrm{BPH}$, the relative ratio of stroma: Epithelium increases with disease progression (35). Fibroblasts, myofibroblasts and smooth muscle cells are the primary stromal components of prostate tissue (36). It has also been revealed that mesenchymal cell markers, including vimentin, fiber binding proteins (fibronectin) and smooth muscle actin- $\alpha$ ( $\alpha$-SMA) serve roles in $\mathrm{BPH}$ progression (37-39).

Studies that assess the mechanism of BPH primarily utilize rodents, including Sprague-Dawley rats (40), Wistar rats (41), as well as non-rodent animal models, including Beagle dogs (12). However, Brown-Norway (BN) rats are rarely employed to model $\mathrm{BPH}$. Although in vitro/in vivo prostate models have been developed to explore the mechanism of benign hyperplasia, to the best of our knowledge, estrogen receptor subtypes, ARs and mesenchymal cell biomarkers (including vimentin, fibronectin and $\alpha$-SMA) have not been assessed in the BN rat model. The aim of the present study was to establish a useful model of BPH and explore the mechanism of sulpiride-induced benign hyperplasia in male $\mathrm{BN}$ rats.

\section{Materials and methods}

Animals and housing. A total of 36 male BN rats (10 weeks old; $280 \pm 20 \mathrm{~g}$ ) were obtained from Beijing Weitong Lihua Experimental Animal Technology Co., Ltd., (Beijing, China) and housed in standard polypropylene cages with sawdust bedding. Drinking water and a pellet diet (Shanghai Shilin Biological Technology Co., Ltd., Shanghai, China) were available ad libitum. Rooms were maintained at $20-26^{\circ} \mathrm{C}$ with $40-70 \%$ humidity and a $12 \mathrm{~h} \mathrm{light/dark} \mathrm{cycle.} \mathrm{The} \mathrm{present} \mathrm{study}$ was approved by the Shanghai Institute of Planned Parenthood Research Animal Care (Shanghai, China).

Animals were divided into three groups $(\mathrm{n}=12)$ according to body weight following 5 days acclimatization as follows: Vehicle group $(290.0 \pm 49.0 \mathrm{~g}), 40 \mathrm{mg} / \mathrm{kg}$ sulpiride group $(292.3 \pm 55.4 \mathrm{~g})$ and $120 \mathrm{mg} / \mathrm{kg}$ sulpiride group $(294.3 \pm 50.5 \mathrm{~g})$. All animal procedures were approved by the Animal Care and Use Committee of Shanghai Institute of Planned Parenthood Research (Shanghai, China) and performed according to the Guide for the Care and Use of Laboratory Animals.

Reagents. Sulpiride (cat. no. SLBG4648V; purity, 100\%) was obtained from Sigma-Aldrich (Merck KGaA, Darmstadt,
Germany). Sodium carboxymethyl cellulose (CMC-Na; cat. no. 20140520; purity, 100\%) was purchased from Sinopharm Group Co., Ltd. (Beijing, China). Sulpiride was dissolved in $0.5 \%$ CMC-Na. The characteristics of primary antibodies are presented in Table I. UltraSensitive ${ }^{\mathrm{TM}}$ SP (Mouse/Rabbit) IHC kit (cat. no. KIT-9710) and PBS were purchased from Fuzhou Maixin Biotechnology Development Co., Ltd. (Fuzhou, China).

Experimental groups. Rats were randomly divided into three groups $(\mathrm{n}=12)$ according to body weight following acclimatization, treated daily with sulpiride $(40$ and $120 \mathrm{mg} / \mathrm{kg}$, intragastrically) or vehicle (0.5\% CMC-Na) for 4 weeks and weighed once per week as previously described (42). The 40 and $120 \mathrm{mg} / \mathrm{kg}$ dosages represent the therapeutic low and high dose used in human treatment $(43,44)$. On day 29 (24 h following final treatment), 3\% pentobarbital sodium (Sigma-Aldrich; Merck KGaA; cat no. P3761; 39 mg/kg) anesthesia was administered via intravenous injection and whole blood samples $(\sim 6-8 \mathrm{ml})$ were obtained from aortaventralis. Following euthanasia, a median abdominal incision was performed to expose the bladder and prostate. Prostates were harvested and divided into three sections, including ventral, dorsal and lateral lobes (VP, DP and LP, respectively) according to their position relative to the urinary bladder. The lobes were weighed and fixed in neutral $10 \%$ formalin for $24 \mathrm{~h}$ at room temperature.

Histopathology. VP, DP and LP tissues were embedded in paraffin, sectioned at $3 \mu \mathrm{m}$ and submitted to routine hematoxylin for $5 \mathrm{~min}$ and eosin for $1 \mathrm{~min}$ (H\&E) staining at room temperature. Histological changes were observed under an optical microscope at magnification, $\mathrm{x} 40$ for the acinar luminal area and magnification, $\mathrm{x} 400$ for the height of the prostatic epithelium (Nikon Eclipse 50i; Nikon Corporation, Tokyo, Japan). The height of the prostatic epithelium (HPE) and acinar luminal area were (ALA) assessed using Nikon NIS-Elements BR 3.1 software (Nikon Corporation). A total of 20 epithelial samples per rat (240 per group) were randomly selected for analysis by a blinded investigator.

Hormone level detection. Blood samples were harvested and centrifuged for $15 \mathrm{~min}\left(2,000 \mathrm{x} \mathrm{g}, 4^{\circ} \mathrm{C}\right)$ to collect serum, which was immediately stored at $-80^{\circ} \mathrm{C}$. Serum PRL (cat. no. DEV9966), FSH (cat.no.LS-F6305), T (cat. no. 582701) and LH (cat. no. 12281601A) levels were determined using specific ELISA assay kits obtained from Demeditec Diagnostics GmbH (Kiel, Germany), LifeSpan BioSciences, Inc. (Seattle, WA, USA), Cayman Chemical Company (Ann Arbor, MI, USA) and ENZO Life Sciences, Inc. (Farmingdale, NY, USA) according to the manufacturers' protocol. The absorbance was read using a microplate reader at $450 \mathrm{~nm}$ (Zenyth 200st; Biochrom Ltd., Cambridge, UK).

Immunohistochemical staining $(I H C)$. Representative blocks of paraffin-embedded prostate tissues were fixed as above and sliced to a $4 \mu \mathrm{m}$ thickness, dewaxed and rehydrated in a descending alcohol series. Sections were heated to $95-100^{\circ} \mathrm{C}$ in a microwave for $20 \mathrm{~min}$ for antigen retrieval and washed with a $0.01 \mathrm{M}$ sodium citrate buffer ( $\mathrm{pH}$ 6.0). The UltraSensitive ${ }^{\mathrm{TM}}$ 
Table I. Characteristics of primary antibodies.

\begin{tabular}{|c|c|c|c|c|c|c|}
\hline Primary antibodies & Supplier & Host species & Dilution & Retrieval & Incubation & Cat. no. \\
\hline PCNA & Santa Cruz Biotechnology, Inc. & Rabbit & $1: 100$ & $10 \min x 2$ & $1 \mathrm{~h}$; room temperature & Sc-7907 \\
\hline Bcl-2 & Santa Cruz Biotechnology, Inc. & Rabbit & $1: 100$ & $10 \min x 2$ & Overnight; $4^{\circ} \mathrm{C}$ & Sc-492 \\
\hline $\mathrm{ER} \alpha$ & Santa Cruz Biotechnology, Inc. & Rabbit & $1: 75$ & $10 \min x 2$ & Overnight; $4^{\circ} \mathrm{C}$ & Sc-7207 \\
\hline $\mathrm{ER} \beta$ & ProteinTech Group, Inc. & Rabbit & $1: 100$ & $10 \min x 2$ & Overnight; $4^{\circ} \mathrm{C}$ & 14007-1-AP \\
\hline AR & Santa Cruz Biotechnology, Inc. & Mouse & $1: 100$ & $10 \min x 2$ & Overnight; $4^{\circ} \mathrm{C}$ & Sc-7305 \\
\hline Vimentin & BD Biosciences & Mouse & $1: 100$ & $10 \min x 2$ & Overnight; $4^{\circ} \mathrm{C}$ & 550513 \\
\hline Fibronectin & BD Biosciences & Mouse & $1: 250$ & $10 \min x 2$ & Overnight; $4^{\circ} \mathrm{C}$ & 610078 \\
\hline$\alpha-\mathrm{SMA}$ & Santa Cruz Biotechnology, Inc. & Mouse & $1: 100$ & $10 \min x 2$ & Overnight; $4^{\circ} \mathrm{C}$ & Sc-53142 \\
\hline
\end{tabular}

PCNA, proliferating cell nuclear antigen; Bcl-2, B-cell lymphoma-2; ER $\alpha$, estrogen receptor- $\alpha$; ER $\beta$, estrogen receptor- $\beta$; AR, androgen receptor; $\alpha$-SMA, $\alpha$-smooth muscle actin; Santa Cruz Biotechnology, Inc., Dallas, TX, USA; ProteinTech Group, Inc., Chicago, IL, USA; BD Biosciences, Franklin Lakes, NJ, USA.

SP (Mouse/Rabbit) IHC kit was used for peroxidase staining. Endogenous peroxidase was quenched with oxidase blocking solution (Reagent A) for 10 min at room temperature. Following blocking with normal non-immune serum (Reagent B) for $10 \mathrm{~min}$ at room temperature, sections were incubated with primary antibodies as presented in Table I. Primary antibodies were replaced with PBS in negative controls. The corresponding secondary antibodies (Reagent C) and Streptomyces antibiotic peroxidase solution (Reagent D) were added successively at room temperature for $10 \mathrm{~min}$, followed by staining with 3,3'-diaminobenzidine for 3-10 $\mathrm{min}$ at $25^{\circ} \mathrm{C}$ ). Sections were then treated with hematoxylin at room temperature for $2 \mathrm{~min}$, dehydrated in a descending series of alcohol, washed with xylene, mounted and observed under an optical microscope (magnification, x400; Nikon Eclipse 50i; Nikon Corporation) by a blinded investigator. Finally, mean optical densities were obtained using Image Pro-Plus 6.0 software (Media Cybernetics, Inc., Rockville, MD, USA).

Statistical analysis. Data were statistically analyzed using SPSS version 11.0 (SPSS, Inc., Chicago, IL, USA) and expressed as the mean \pm standard deviation. Statistical comparisons were performed using one-way analysis of variance followed by Tukey's post hoc multiple comparison test. If statistically significant, differences between control and treatment groups were assessed using a least-squares means test. $\mathrm{P}<0.05$ was considered to indicate a statistically significant difference.

\section{Results}

Body and prostate lobe weights. During the 4 weeks of sulpiride administration, animal body weights increased slightly compared with controls, however no significant differences were observed (Table II). Following treatment with 40 and $120 \mathrm{mg} / \mathrm{kg} /$ day sulpiride, prostate weight and relative prostate weight increased in a dose-dependent manner (Table II). In addition, treatment with sulpiride resulted in a dose-dependent increase of DP and LP wet and relative weights (Table III). In particular, LP in sulpiride groups was significantly increased $(\mathrm{P}<0.05$ for sulpiride $40 \mathrm{mg} / \mathrm{kg}$ and $\mathrm{P}<0.01$ for sulpiride $120 \mathrm{mg} / \mathrm{kg}$ ). VP and relative weights in the $40 \mathrm{mg} / \mathrm{kg}$ sulpiride group were reduced compared with the control values, while sulpiride $120 \mathrm{mg} / \mathrm{kg}$ demonstrated higher values (Table III).

Histology. Histologically, proliferative features were more prominent in the sulpiride groups compared with the control group (Fig. 1). H\&E staining revealed glandular prostatic hyperplasia with increased HPE and ALA in VP and LP of 40 and $120 \mathrm{mg} / \mathrm{kg}$ sulpiride groups (Figs. 1 and 2). In the sulpiride groups, the HPE of LP was significantly increased compared with control values $(\mathrm{P}<0.01$; Table IV). Following 4 weeks of treatment with sulpiride, HPE was significantly increased in VP and LP tissues in the sulpiride groups compared with the control group $(\mathrm{P}<0.01$; Table IV), particularly in the $120 \mathrm{mg} / \mathrm{kg}$ sulpiride group.

In the sulpiride groups, the ALAs of lobes were significantly increased compared with the controls, particularly in LP tissues $(\mathrm{P}<0.01$; Table V; Fig. 3). Following 4 weeks of treatment with sulpiride, ALA in LP tissues was significantly increased compared with control values $(\mathrm{P}<0.01$; Table $\mathrm{V})$, particularly in the $120 \mathrm{mg} / \mathrm{kg}$ sulpiride (Table V; Fig. 3).

Serum PRL, FSH, T and LH levels. All groups treated with sulpiride exhibited higher PRL levels compared with the control group, particularly following treatment with $120 \mathrm{mg} / \mathrm{kg}$ sulpiride $(\mathrm{P}<0.001$; Table VI). Furthermore, PRL levels demonstrated a dose-dependent increase. All groups treated with sulpiride had significantly increased $\mathrm{T}$ levels compared with the control group $(\mathrm{P}<0.01$ for sulpiride $120 \mathrm{mg} / \mathrm{kg}$ and $\mathrm{P}<0.001$ for sulpiride $40 \mathrm{mg} / \mathrm{kg}$ ). Compared with the control group, the LH levels were significantly decreased in the sulpiride groups $(\mathrm{P}<0.001$; Table VI). Additionally, the results determined that LH levels decreased as the sulpiride dose increased. FSH levels were increased in the sulpiride groups compared with controls, particularly in the $40 \mathrm{mg} / \mathrm{kg}$ sulpiride group $(\mathrm{P}<0.001$; Table VI).

PCNA, Bcl-2, ER $\alpha, E R \beta, A R$, vimentin, fibronectin and $\alpha$-SMA expression levels in prostate lobes. The expression levels of PCNA, Bcl-2, ER $\alpha, \mathrm{ER} \beta, \mathrm{AR}$ and mesenchymal cell markers (including vimentin, fibronectin and $\alpha$-SMA) 
Table II. Effects of Sulpiride on body and prostate weight of benign hyperplasia prostate modeled Brown-Norway rats.

\begin{tabular}{lcccccc}
\hline & \multicolumn{3}{c}{ Body weight $(\mathrm{g})$} & & \multicolumn{2}{c}{ Prostate } \\
\cline { 2 - 3 } Group & Initial & Final & Weight gain & & Weight $(\mathrm{g})$ & Relative weight $(/ 100)$ \\
\hline Control & $290.0 \pm 49.0$ & $305.9 \pm 39.1$ & $15.0 \pm 37.1$ & & $0.567 \pm 0.140$ & $0.185 \pm 0.034$ \\
Sulpiride $(40 \mathrm{mg} / \mathrm{kg})$ & $292.3 \pm 55.4$ & $312.5 \pm 41.5$ & $20.0 \pm 45.3$ & & $0.637 \pm 0.095$ & $0.206 \pm 0.033$ \\
Sulpiride $(120 \mathrm{mg} / \mathrm{kg})$ & $294.3 \pm 50.5$ & $312.9 \pm 42.8$ & $18.6 \pm 44.7$ & & $0.784 \pm 0.200^{\mathrm{a}}$ & $0.248 \pm 0.036^{\mathrm{a}}$ \\
\hline
\end{tabular}

Relative weight $=($ organ weight/terminal body weight $) \times 100$. Data are presented as the mean \pm standard deviation $(\mathrm{n}=12) .{ }^{a} \mathrm{P}<0.05 \mathrm{vs}$. control .

Table III. Effects of sulpiride on prostate lobe weight of benign hyperplasia prostate modeled Brown-Norway rats.

\begin{tabular}{|c|c|c|c|c|c|c|}
\hline \multirow[b]{2}{*}{$\begin{array}{l}\text { Experimental } \\
\text { group }\end{array}$} & \multicolumn{2}{|c|}{ VP } & \multicolumn{2}{|c|}{ DP } & \multicolumn{2}{|c|}{ LP } \\
\hline & Weight (g) & $\begin{array}{c}\text { Relative weight } \\
\qquad(/ 1,000)\end{array}$ & Weight (g) & $\begin{array}{l}\text { Relative weight } \\
\qquad(/ 1,000)\end{array}$ & Weight (g) & $\begin{array}{l}\text { Relative weight } \\
\qquad(/ 1,000)\end{array}$ \\
\hline Control & $0.361 \pm 0.087$ & $1.170 \pm 0.190$ & $0.110 \pm 0.053$ & $0.350 \pm 0.150$ & $0.096 \pm 0.034$ & $0.320 \pm 0.140$ \\
\hline Sulpiride $(40 \mathrm{mg} / \mathrm{kg})$ & $0.347 \pm 0.061$ & $1.128 \pm 0.234$ & $0.148 \pm 0.054^{\mathrm{a}}$ & $0.472 \pm 0.167^{\mathrm{a}}$ & $0.142 \pm 0.022^{\mathrm{a}}$ & $0.459 \pm 0.076^{\mathrm{a}}$ \\
\hline Sulpiride $(120 \mathrm{mg} / \mathrm{kg})$ & $0.419 \pm 0.083$ & $1.334 \pm 0.148$ & $0.192 \pm 0.088^{\mathrm{b}}$ & $0.595 \pm 0.221^{\mathrm{b}}$ & $0.173 \pm 0.068^{b}$ & $0.549 \pm 0.171^{\mathrm{b}}$ \\
\hline
\end{tabular}

Relative weight=(organ weight/terminal body weight) $\mathrm{x} 1,000$. Data were presented as the mean \pm standard deviation $(\mathrm{n}=12) .{ }^{\mathrm{a}} \mathrm{P}<0.05$ and ${ }^{\mathrm{b}} \mathrm{P}<0.01$ vs. controls. VP, ventral prostate; DP, dorsal prostate; LP, lateral prostate.

were immunohistochemically analyzed to further assess the sulpiride-induced signaling pathway in BPH. The results demonstrated that PCNA was primarily expressed in the nucleus of epithelial cells (Fig. 4A). Compared with the control group, sulpiride treatment resulted in increased PCNA levels in LP $(\mathrm{P}<0.01$; Fig. 4C); however, no significant differences were observed in VP and DP. The Bcl-2 protein was primarily expressed in the cytoplasm and was significantly increased in VP, DP and LP tissues in the sulpiride groups compared with the controls $(\mathrm{P}<0.05$ or $\mathrm{P}<0.01 ;$ Fig. 4).

The results of IHC demonstrated that $\mathrm{ER} \alpha$ was primarily distributed in the epithelial cell nucleus (Fig. 5A) and ER $\beta$ was expressed abundantly in the basal epithelial layer within cell nuclei (Fig. 5B). In the $120 \mathrm{mg} / \mathrm{kg}$ sulpiride group, ER $\alpha$ levels in LP were slightly increased compared with control values $(\mathrm{P}<0.05$; Fig. 5D). Similar results were observed in the $40 \mathrm{mg} / \mathrm{kg}$ sulpiride group ( $\mathrm{P}<0.01$; Fig. 5D). AR was expressed in the nucleus and cytoplasm of epithelial cells, but remained predominantly nuclear. The expression of AR was similar to that of ER $\alpha$, unlike ER $\beta$ (Fig. 5D-F). Sulpiride $40 \mathrm{mg} / \mathrm{kg}$ significantly upregulated ER $\alpha$ and AR levels in LP $(\mathrm{P}<0.01)$ whilst sulpiride $120 \mathrm{mg} / \mathrm{kg}$ downregulated $\mathrm{ER} \beta, \mathrm{ER} \beta$ was significantly increased in LP tissues treated with sulpiride $40 \mathrm{mg} / \mathrm{kg}(\mathrm{P}<0.05$; Fig. 5E). The effects of sulpiride treatment at $40 \mathrm{mg} / \mathrm{kg}$ were markedly more pronounced than those exhibited at $120 \mathrm{mg} / \mathrm{kg}$.

Vimentin constitutes a specific protein marker of fibroblast cells (45) and was primarily expressed in mesenchymal cells (Fig. 6). Compared with the control group, treatment with 40 and $120 \mathrm{mg} / \mathrm{kg}$ sulpiride significantly upregulated vimentin in LP tissues $(\mathrm{P}<0.01$; Fig. 6D); however no significant differences in vimentin levels were detected in VP and DP tissues.
Fibronectin was primarily expressed in mesenchymal cells (Fig. 6B). Compared with controls, fibronectin expression in DP and LP following treatment with $40 \mathrm{mg} / \mathrm{kg}$ sulpiride was significantly increased $(\mathrm{P}<0.05$ and $\mathrm{P}<0.01$, respectively; Fig. $6 \mathrm{E})$, as well as in LP tissues treated with $120 \mathrm{mg} / \mathrm{kg}$ sulpiride $(\mathrm{P}<0.05$, $\mathrm{P}<0.01)$. However, fibronectin protein levels in VP from the $40 \mathrm{mg} / \mathrm{kg}$ treated group and VP and DP tissues treated with $120 \mathrm{mg} / \mathrm{kg}$ exhibited no significant differences. $\alpha$-SMA, a specific marker of myofibroblasts, was primarily expressed in the stromal cells of the prostate (Fig. 6C). Compared with controls, $\alpha$-SMA levels were increased in VP and LP tissues following treatment with $40 \mathrm{mg} / \mathrm{kg}$ sulpiride $(\mathrm{P}<0.05$; Fig. $6 \mathrm{~F})$; however, levels decreased in LP tissues following the administration of $120 \mathrm{mg} / \mathrm{kg}$ sulpiride. Furthermore, $\alpha$-SMA levels in DP tissues following treatment with $40 \mathrm{mg} / \mathrm{kg}$ sulpiride and in VP and DP tissues following $120 \mathrm{mg} / \mathrm{kg}$ sulpiride treatment, demonstrated no significant differences (Fig. 6F).

\section{Discussion}

The results of the present study revealed the mechanism of sulpiride-induced BPH in male BN rats. Sulpiride stimulates PRL secretion from the pituitary gland and causes prostate toxicity (8). The present study aimed to establish a useful model to assess the mechanism of BPH development and the mechanism of sulpiride-induced BPH in male BN rats.

$\mathrm{BPH}$ originates in the transitional and peripheral zones of the humans prostate (46). Murine dorsal and lateral prostate lobes (DLP) are homologous with the peripheral zone in the human prostate and proliferation is more evident in the DLP than in the VP in transgenic mice (47). The current 
A

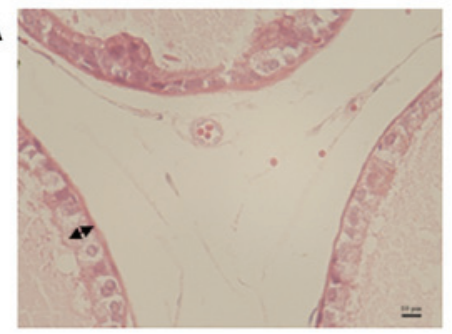

B

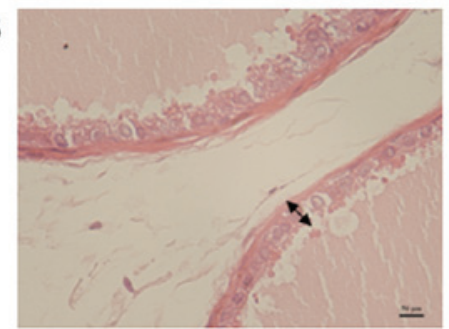

D

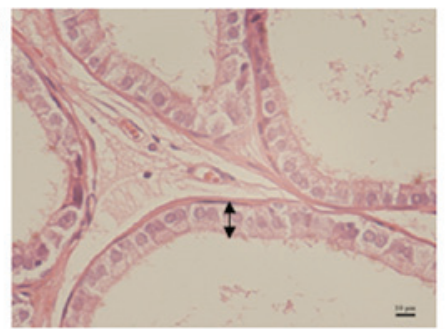

G

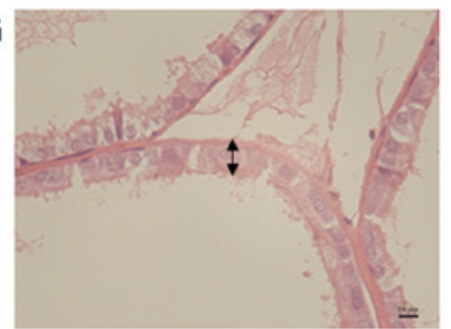

E

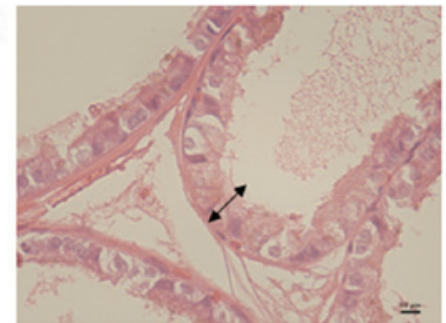

$\mathrm{H}$

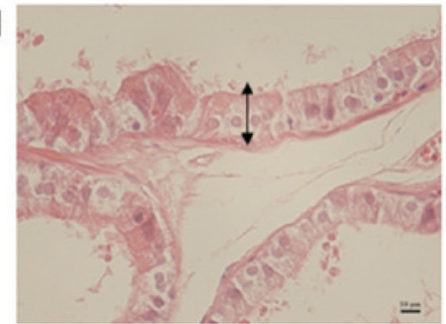

C

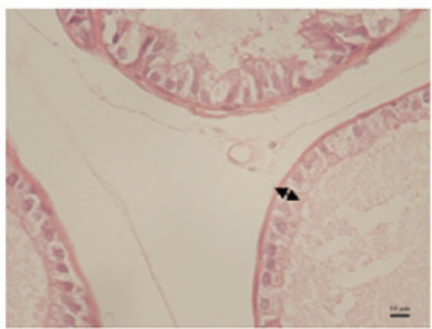

$\mathrm{F}$
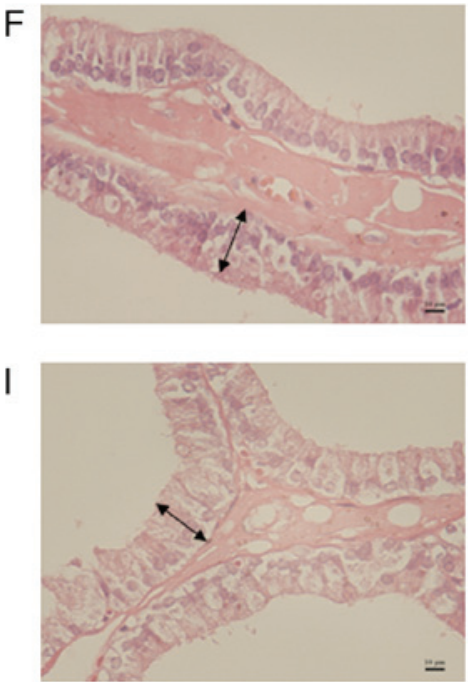

Figure 1. Histological changes in prostate lobes from Brown-Norway rats: Height of prostatic epithelium. Representative sections of comparable regions of the (A) ventral, (B) dorsal and (C) lateral prostatic lobes in the control group. Representative sections of (D) ventral, (E) dorsal and (F) lateral prostatic lobes in rats treated with $40 \mathrm{mg} / \mathrm{kg}$ sulpiride. Representative sections of $(\mathrm{G})$ ventral, $(\mathrm{H})$ dorsal and (I) lateral prostatic lobes in the rats treated with $120 \mathrm{mg} / \mathrm{kg}$ sulpiride. Magnification, $\mathrm{x} 400$. Scale bar, $10 \mu \mathrm{m}$. Bidirectional arrows represent the height of the prostatic epithelium.

A

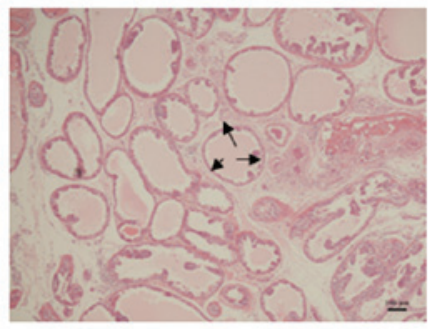

D

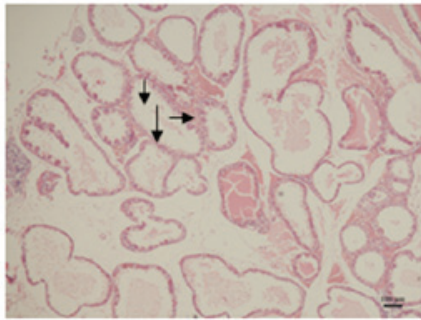

$\mathrm{G}$

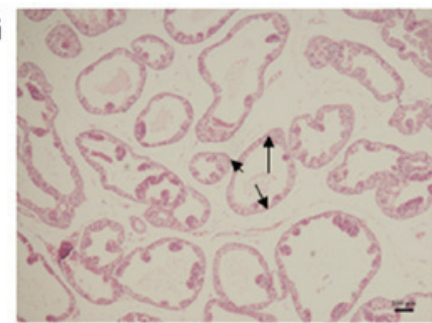

B

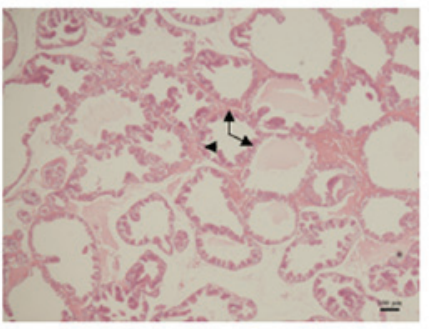

E

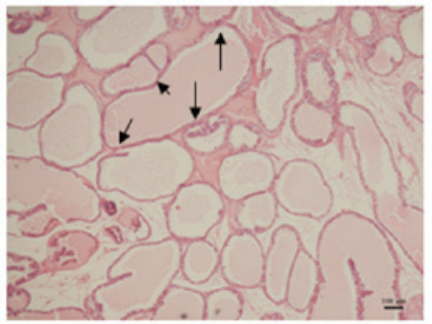

$\mathrm{H}$

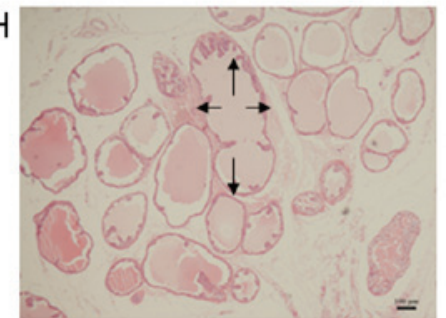

C

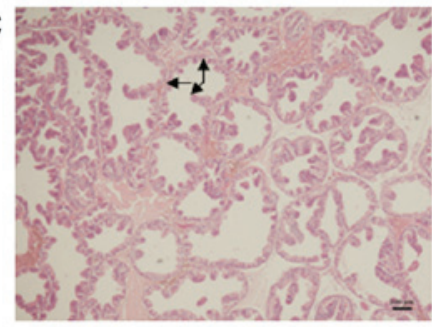

F

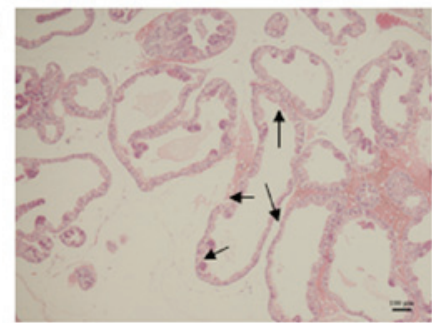

I

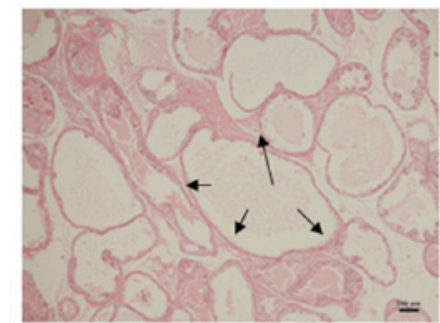

Figure 2. Histological changes in prostate lobes from Brown-Norway rats: Acinar luminal area. Representative sections of comparable regions of the (A) ventral, (B) dorsal and (C) lateral prostatic lobes in the control group. Representative sections of (D) ventral, (E) dorsal and (F) lateral prostatic lobes in rats treated with $40 \mathrm{mg} / \mathrm{kg}$ sulpiride. Representative sections of $(\mathrm{G})$ ventral, $(\mathrm{H})$ dorsal and (I) lateral prostatic lobes in the rats treated with $120 \mathrm{mg} / \mathrm{kg}$ sulpiride. Magnification, $\mathrm{x} 400$. Scale bar, $10 \mu \mathrm{m}$. Bidirectional arrows represent the acinar luminal area. 
Table IV. Effects of sulpiride on the height of prostatic epithelium of benign hyperplasia prostate modeled Brown-Norway rats.

\begin{tabular}{lccr}
\hline Experimental group & $\mathrm{VP}(\mu \mathrm{m})$ & $\mathrm{DP}(\mu \mathrm{m})$ & $\mathrm{LP}(\mu \mathrm{m})$ \\
\hline Control & $8.54 \pm 1.61$ & $11.41 \pm 1.41$ & $13.41 \pm 1.71$ \\
Sulpiride $(40 \mathrm{mg} / \mathrm{kg})$ & $14.46 \pm 1.49^{\mathrm{a}}$ & $20.27 \pm 3.54^{\mathrm{a}}$ & $25.14 \pm 4.50^{\mathrm{a}}$ \\
Sulpiride $(120 \mathrm{mg} / \mathrm{kg})$ & $15.92 \pm 2.60^{\mathrm{a}}$ & $19.41 \pm 4.05^{\mathrm{a}}$ & $28.77 \pm 3.62^{\mathrm{a}}$ \\
\hline
\end{tabular}

${ }^{\mathrm{a}} \mathrm{P}<0.01$ vs. control. VP, ventral prostate; DP, dorsal prostate; LP, lateral prostate. Data were presented as the mean \pm standard deviation $(\mathrm{n}=12)$.

Table V. Effects of sulpiride on prostate acinar luminal areas of benign hyperplasia prostate modeled Brown-Norway rats.

\begin{tabular}{lccr}
\hline Experimental group & VP $\left(\mu \mathrm{m}^{2}\right)$ & $\mathrm{DP}\left(\mu \mathrm{m}^{2}\right)$ & $\mathrm{LP}\left(\mu \mathrm{m}^{2}\right)$ \\
\hline Control & $22,735.78 \pm 9,992.60$ & $25,769.59 \pm 10,308.27$ & $17,454.82 \pm 5,506.35$ \\
Sulpiride $(40 \mathrm{mg} / \mathrm{kg})$ & $36,013.52 \pm 8,837.63^{\mathrm{a}}$ & $66,713.71 \pm 6,123.32^{\mathrm{a}}$ & $88,233.29 \pm 7,336.71^{\mathrm{a}}$ \\
Sulpiride $(120 \mathrm{mg} / \mathrm{kg})$ & $49,829.91 \pm 9,301.02^{\mathrm{a}}$ & $59,617.50 \pm 9,814.00^{\mathrm{a}}$ & $101,443.90 \pm 7,374.53^{\mathrm{a}}$ \\
\hline
\end{tabular}

${ }^{a} \mathrm{P}<0.01$ vs. control. VP, ventral prostate; DP, dorsal prostate; LP, lateral prostate. Data were presented as the mean \pm standard deviation ( $\mathrm{n}=12$ ).

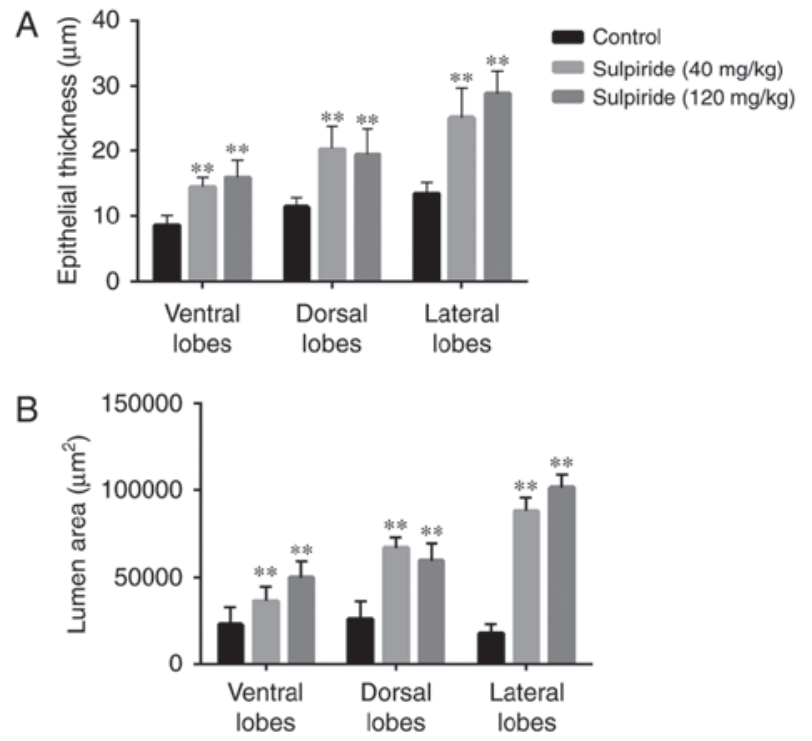

Figure 3. Changes in the prostatic epithelial height and acinar luminal area prostate lobes from Brown-Norway rats. Following treatment with 40 or $120 \mathrm{mg} / \mathrm{kg}$ sulpiride for 4 weeks, (A) epithelial height and (B) the acinar lumen area of the lateral prostatic epithelium were observed in rats. ${ }^{* *} \mathrm{P}<0.01$ vs. control group.

histological findings suggest that sulpiride significantly induces glandular hyperplasia in LP as follows: Increases of ALA and HPE corroborated experimental findings by Van Coppenolle et al (8). Ahonen et al (15) demonstrated that PRL stimulates proliferation and acts as an androgenindependent suppressor of apoptosis in prostate epithelial cells, leading to prostate epithelial hyperplasia in DP and LP by using long-term organ cultures of rat prostate tissue. In addition, Słuczanowska-Głąbowska et al (9) demonstrated that the columnar and cubical cells of the epithelium were tall and had irregular disposition in sites of hyperplasia of the
DP and LP in sexually mature male Wistar rats treated with metoclopramide, while no changes were observed in the VP. As previously mentioned, LP hyperplasia in sulpiride-injected animals may be caused by increased PRL levels (32).

Aside from androgens, the effects of serum PRL on prostate cell differentiation are important (32). It remains unclear whether PRL acts synergistically with or independently of T and current data remains controversial $(6,12,48)$. The results of the present study revealed increased PRL, FSH and T levels in sulpiride-treated groups compared with controls, while LH levels decreased. The present study also demonstrated that PRL and T levels increased, which is in disagreement with the results of the study by Van Coppenolle et al (8). This discrepancy may result from the use of different animal species in each study. The results of the present study may also be explained by the reduced activity of $5 \alpha$-reductase, which can cause increased serum T levels (49). However, this requires further study to confirm. Furthermore, Kindblom et al (50) demonstrated that PRL stimulates BPH in mice independently of $\mathrm{T}$. This suggests that PRL affects the prostate and increases $\mathrm{T}$ levels, thereby promoting $\mathrm{BPH}$ in $\mathrm{BN}$ rats, which is similar to the results obtained from Wennbo et al (51). Rubin et al $(52,53)$ confirmed the prior hypothesis that PRL stimulates $\mathrm{T}$ secretion, which reported that PRL accentuates the effects of androgens in the stimulation of prostate growth and function. Additionally, Van Coppenolle et al (8) demonstrated that $\mathrm{T}$ levels are higher in controls compared with animals treated with sulpiride, which is not congruent with the aforementioned results. Previous studies have indicated that an increase in PRL inhibits gonadotrop-releasing hormone $(\mathrm{GnRH})$ release from the hypothalamus and reduces $\mathrm{LH}$ release via a negative feedback regulatory mechanism $(54,55)$. The structure and function of the prostate are influenced by the hypothalamus-pituitary-gonadal axis (56), while tissue growth and hormone secretion are primarily affected by $\mathrm{T}$ regulation (57). In turn, T secretion is controlled by $\mathrm{LH}$ and 
Table VI. Plasma PRL, FSH, T and LH levels.

\begin{tabular}{lcccc}
\hline Experimental group & PRL $(\mathrm{ng} / \mathrm{ml})$ & FSH $(\mathrm{ng} / \mathrm{ml})$ & T $(\mathrm{pg} / \mathrm{ml})$ & LH $(\mathrm{mIU} / \mathrm{ml})$ \\
\hline Control & $5.87 \pm 3.16$ & $4.82 \pm 1.67$ & $197.27 \pm 170.63$ & $701.58 \pm 515.83$ \\
Sulpiride $(40 \mathrm{mg} / \mathrm{kg})$ & $57.48 \pm 15.52^{\mathrm{b}}$ & $7.46 \pm 2.98^{\mathrm{b}}$ & $535.07 \pm 352.90^{\mathrm{b}}$ & $575.03 \pm 123.69^{\mathrm{b}}$ \\
Sulpiride $(120 \mathrm{mg} / \mathrm{kg})$ & $106.82 \pm 27.2^{\mathrm{b}}$ & $5.36 \pm 1.00$ & $273.16 \pm 92.44^{\mathrm{a}}$ & $367.61 \pm 265.64^{\mathrm{b}}$ \\
\hline
\end{tabular}

PRL, prolactin; FSH, follicle-stimulating hormone; T, testosterone; $\mathrm{LH}$, luteinizing hormone. Data were presented as the mean \pm standard deviation $(\mathrm{n}=12)$. ${ }^{\mathrm{a}} \mathrm{P}<0.01$ and ${ }^{\mathrm{b}} \mathrm{P}<0.001$ vs. controls.

A

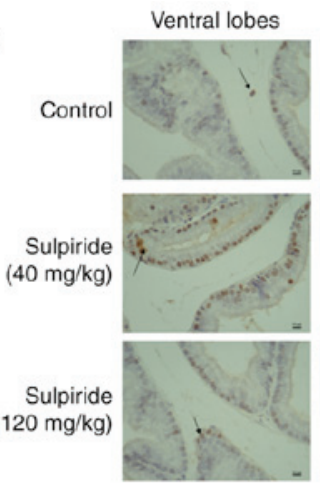

C
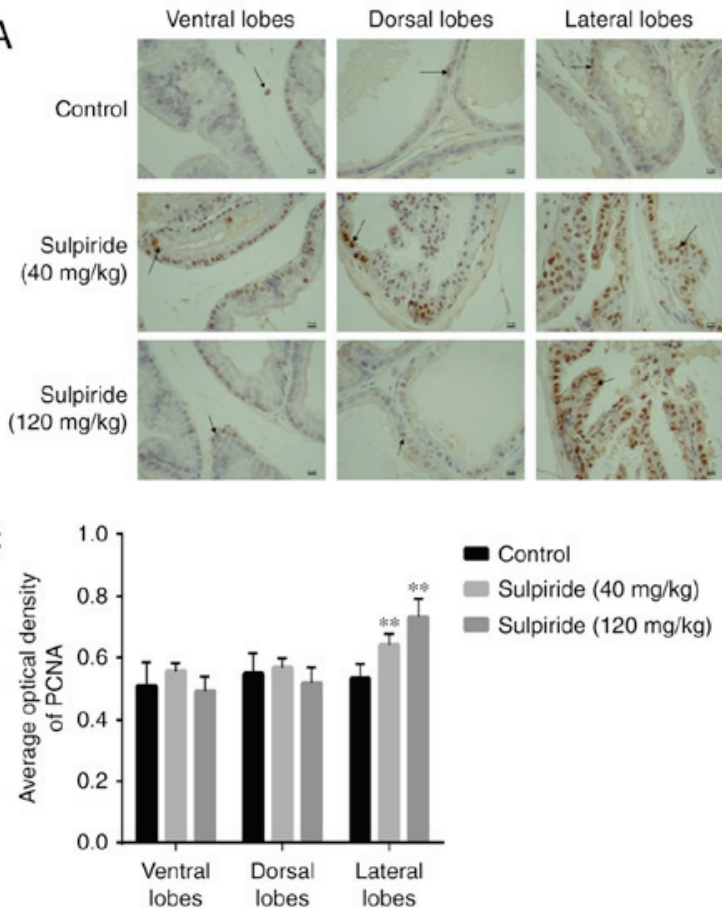

D

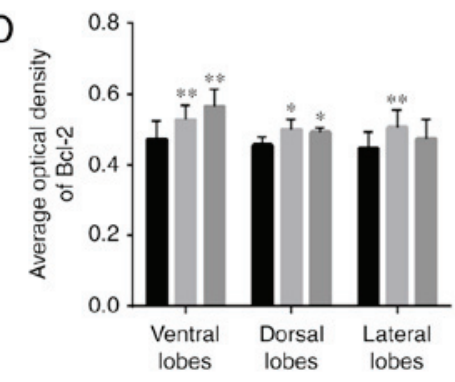

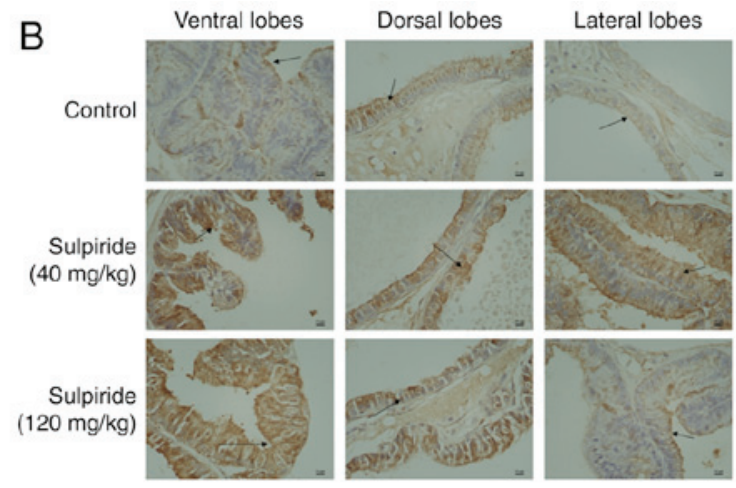

- Control

- Sulpiride $(40 \mathrm{mg} / \mathrm{kg})$

Sulpiride $(120 \mathrm{mg} / \mathrm{kg})$

Figure 4. Immunohistochemical localization of (A) PCNA and (B) Bcl-2 in tissue sections of prostatic lobes in sulpiride treated Brown-Norway rats. Black arrows indicate strong positive PCNA and Bcl-2 signals. Semi-quantitative analysis of (C) PCNA and (D) Bcl-2 staining. Magnification, x400. Scale bar, $10 \mu \mathrm{m} .{ }^{*} \mathrm{P}<0.05$ and ${ }^{* *} \mathrm{P}<0.01$ vs. control group. PCNA, proliferating cell nuclear antigen; Bcl-2, B-cell lymphoma-2.

FSH $(58,59)$. Sulpiride has an effect on the hypothalamic tuberoinfundibular dopaminergic neurons at the pituitary and increases PRL release (60). Furthermore, PRL stimulates the release of endogenous opioids, which strongly inhibits GnRH release (61). LH was downregulated and FSH was upregulated via the feedback regulation mechanism utilized by the hypothalamus-pituitary-gonadal axis; elevated FSH stimulates the release of $\mathrm{T}$, which in turn inhibits GnRH release.

The results of the present study indicate that sulpiride promotes prostate growth in BN rats by increasing PRL and $\mathrm{T}$ levels. In addition, synergistic effects between PRL and T were demonstrated. PCNA is used as a proliferation marker in the rat prostate (28). IHC results in the present study revealed that PCNA was primarily expressed in the nucleus of epithelial cells. In addition, PCNA expression in LP samples was significantly increased following sulpiride treatment compared with the control group. However, PCNA levels were unchanged in VP and DP samples. A previous study has indicated that the VP and DP in BN rats are insensitive to PRL, no PCNA overexpression was detected in the present study (47).
It has been demonstrated that $\mathrm{Bcl}-2$ reduces cell apoptosis in prostate tissues (62). As revealed by IHC in the present study, the $\mathrm{Bcl}-2$ protein was primarily expressed in the cytoplasm of epithelial cells and its levels increased significantly in rats treated with sulpiride with the exception of LP at sulpiride $120 \mathrm{mg} / \mathrm{kg}$. Van Coppenolle et al (8) demonstrated that Bcl-2 expression is increased in the LP of sulpiride treated rats. In the present study, LP hyperplasia may be explained by the PRL-induced proliferation as mediated by PCNA overexpression and apoptosis inhibition via Bcl-2 overexpression. These experimental results suggest that sulpiride treatment promotes proliferation and inhibits epithelial cell apoptosis, promoting prostate epithelial hyperplasia.

Estrogen receptors belong to the nuclear receptor family of proteins that includes ER $\alpha$ and ER $\beta$; the former serves a role in the promotion of prostate cell proliferation and the latter exerts beneficial effects by repressing prostate growth (63). Sulpiride competes with estradiol for the ER $\alpha$ binding due to its structural similarity and binds specific DNA sequences to induce target genes following nuclear entry (64). As demonstrated in 
A

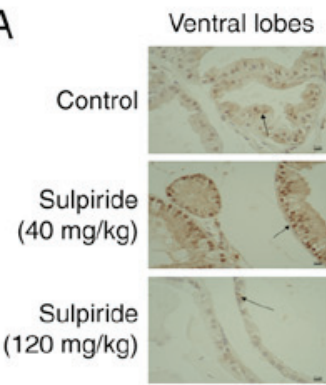

C

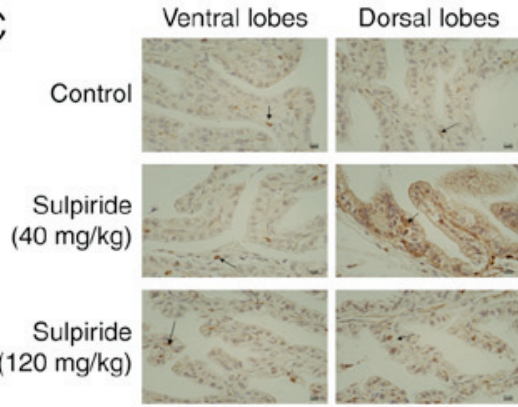

E

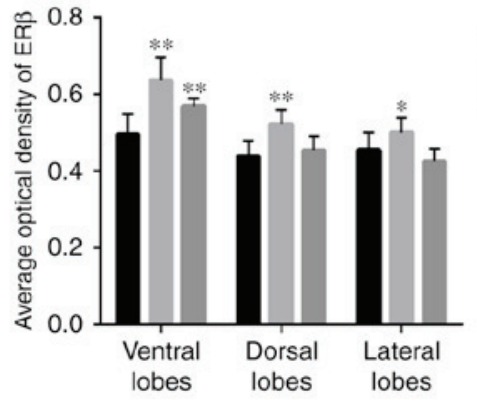

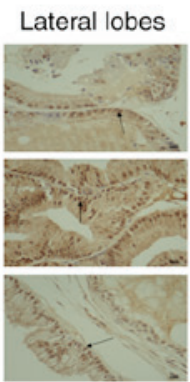

Lateral lobes
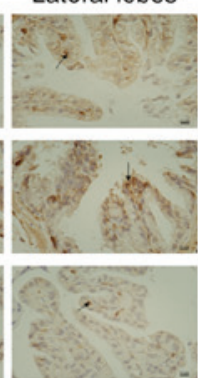

- Control

Sulpiride $(40 \mathrm{mg} / \mathrm{kg})$

- Sulpiride $(120 \mathrm{mg} / \mathrm{kg}$ )
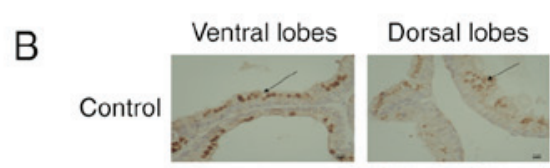

Lateral lobes
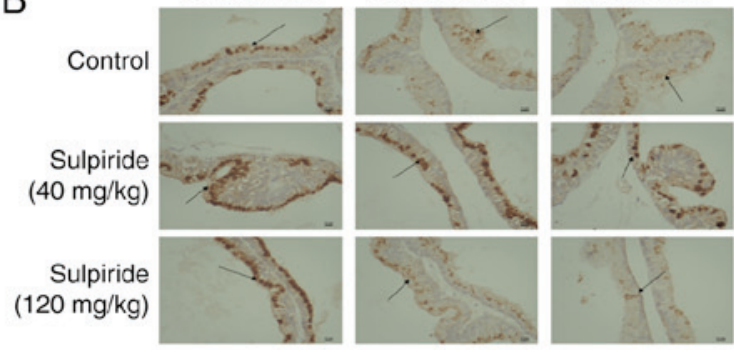

D

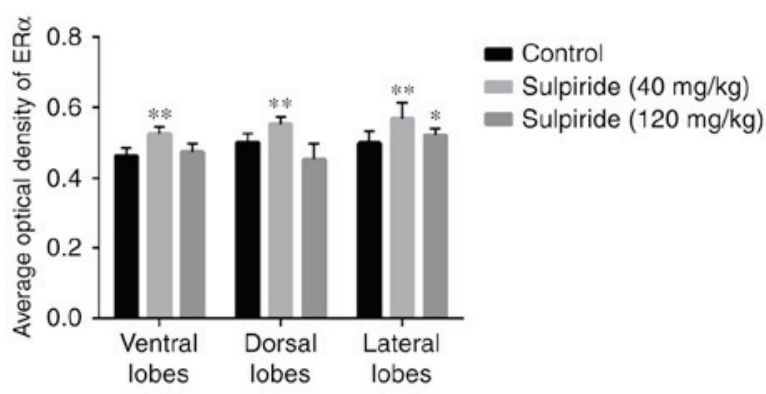

F

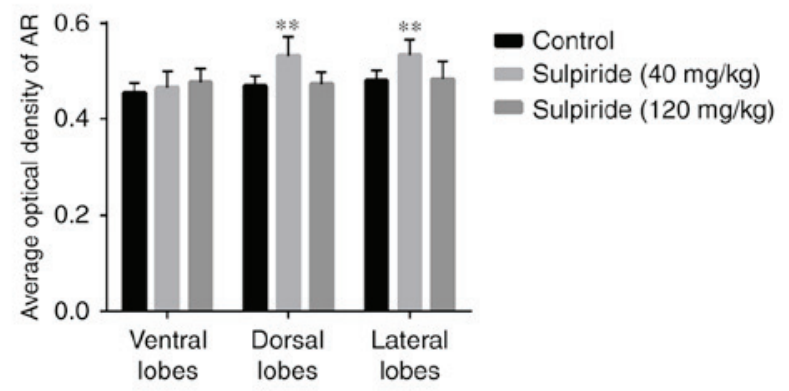

Figure 5. Immunohistochemical localization of (A) ER $\alpha,(B) E R \beta$ and (C) AR in sulpiride treated Brown-Norway rat prostate tissues. Black arrows indicate strong positive ER $\alpha, E R \beta$ and AR signals. Semi-quantitative analysis of (D) ER $\alpha$, (E) ER $\beta$ and (F) AR staining. Magnification, $\mathrm{x} 400$. Scale bar, $100 \mu \mathrm{m}$. ${ }^{*} \mathrm{P}<0.05$ and ${ }^{* *} \mathrm{P}<0.01$ vs. control group. ER $\alpha$, Estrogen receptor- $\alpha$; ER $\beta$, Estrogen receptor- $\beta$; AR, androgen receptor.

the present study, ER $\alpha$ and ER $\beta$ are primarily expressed in the nucleus of epithelial cells. In sulpiride treatment groups, ER $\alpha$ levels in LP tissues were significantly increased compared with control values. The $40 \mathrm{mg} / \mathrm{kg}$ sulpiride group significantly increased ER $\alpha$ levels in different lobes. The prostate is an androgen-dependent organ and AR serves a pivotal role in the regulation of its function, growth and differentiation (65). The transcription factor AR is activated by its ligand, binding a specific androgen response element to promote transcription (33). In the present study, AR was expressed in the nucleus and cytoplasm of epithelial cells, with levels increasing in VP with the dosage of $120 \mathrm{mg} / \mathrm{kg}$ sulpiride. However, $40 \mathrm{mg} / \mathrm{kg}$ sulpiride group significantly increased AR in DP and LP tissues, more so than the $120 \mathrm{mg} / \mathrm{kg}$ dosage. The expression trend of AR was similar to that of ER $\alpha$, but opposite to that of ER $\beta$. Higher AR expression in the lateral lobes of $\mathrm{BN}$ rats may be explained by the following mechanisms. Banerjee et al (66) reported that AR expression is not dependent on T, as AR levels remain unchanged in castrated rats. In addition, SluczanowskaGlabowska et al (9) demonstrated that AR is elevated in LP tissues of the experimental group, but lower in the VP and DP tissues. Prins et al (67) revealed that increased PRL leads to AR upregulation in the LP of experimental animals. Furthermore, Holland and Lee (68) demonstrated that increased serum PRL and decreased $\mathrm{T}$ results in the increased sensitivity of the LP to PRL. As demonstrated in the present study, ER $\alpha$ and AR levels were increased following sulpiride treatment, indicating that sulpiride causes LP hyperplasia of the prostate via the $\mathrm{ER} \alpha$ and AR signaling pathways.

The present study evaluated the expression of stromal cell biomarkers following sulpiride administration. The stromal compartment contains fibroblasts, vasculature, nerves and immune components $(69,70)$. Mesenchymal cells consist of fibroblasts, myofibroblasts and smooth muscle cells (71). Mesenchymal cell markers, including vimentin, $\alpha$-SMA and fibronectin, are associated with the development of prostate tissues (72-76). As demonstrated by IHC in the present study, vimentin, fibronectin and $\alpha$-SMA were primarily expressed in mesenchymal cells. In addition, vimentin expression in LP was significantly increased following the administration of 40 and $120 \mathrm{mg} / \mathrm{kg}$ sulpiride. These findings suggest that sulpiride also causes hyperplasia in the stromal component of LP, indicating that $\mathrm{BPH}$ is a proliferative stromal disease, similar to spontaneous prostatic hyperplasia (4).

PCNA as a proliferation marker and Bcl-2 as an anti-apoptotic marker mediate cell proliferation and apoptosis, respectively. The present study demonstrated that the expression of PCNA and Bcl-2 was upregulated in LP of $40 \mathrm{mg} / \mathrm{kg}$ 

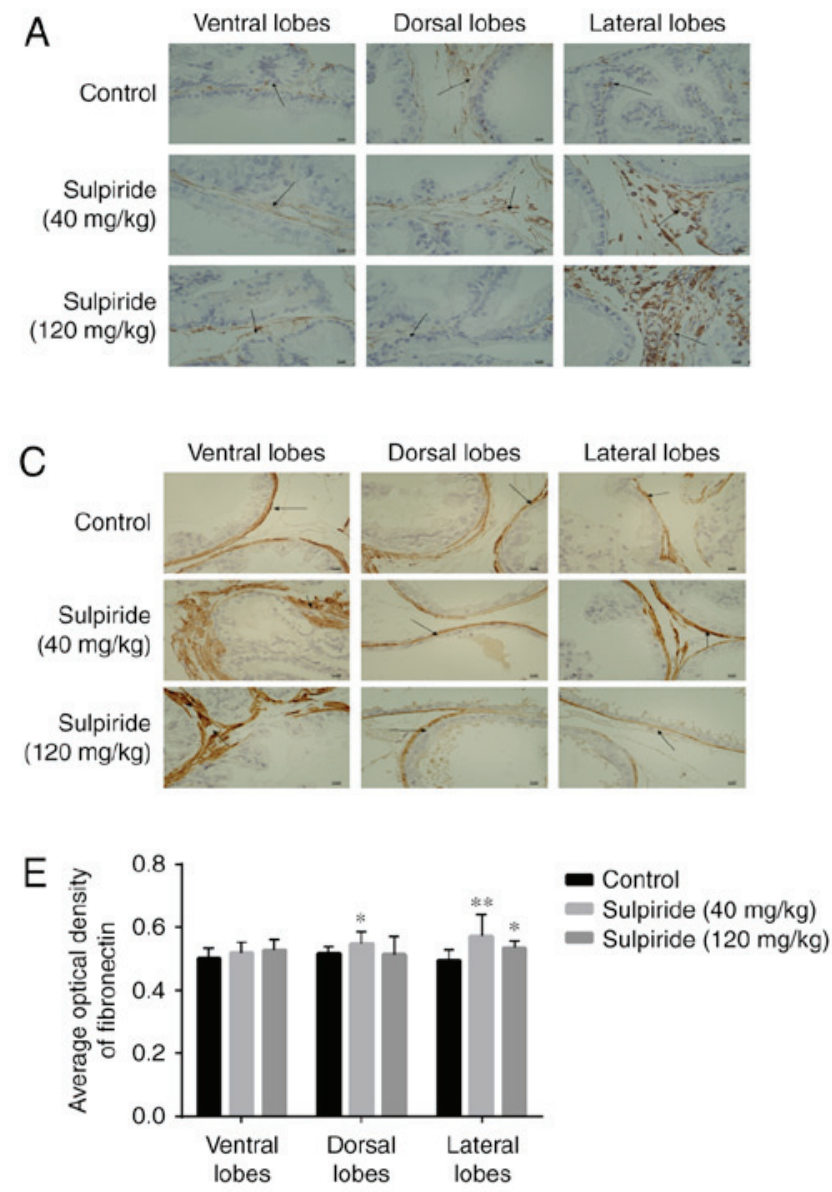
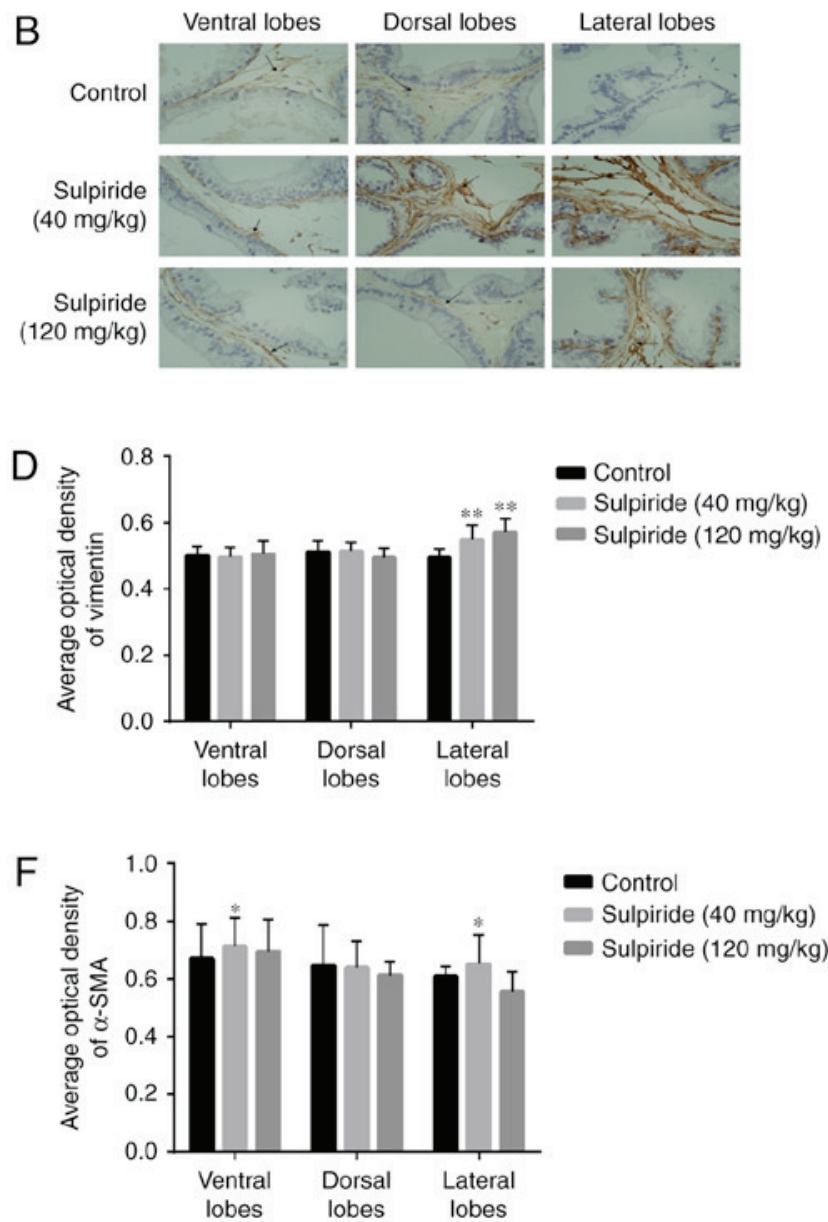

Figure 6. Immunohistochemical localization of (A) vimentin, (B) fibronectin and (C) $\alpha$-SMA in sulpiride treated Brown-Norway rat prostate tissues. Black arrows indicate strong positive vimentin, fibronectin and $\alpha$-SMA signals. Semi-quantitative analysis of (D) vimentin, (E) fibronectin and (F) $\alpha$-SMA staining. Magnification, $\mathrm{x} 400$. Scale bar, $100 \mu \mathrm{m}$. ${ }^{*} \mathrm{P}<0.05$ and ${ }^{* *} \mathrm{P}<0.01$ vs. control group. $\alpha$-SMA, $\alpha$-smooth muscle actin.

sulpiride group. Van Coppenolle et al (8) demonstrated that PRL stimulates Bcl-2 expression in the prostate gland of sulpiride-treated Wistar rats and inhibits prostate cell apoptosis. The results of the present study revealed that $\mathrm{BN}$ rats treated with sulpiride exhibited higher PRL levels compared with control rats. It was hypothesized that higher Bcl-2 levels caused by higher PRL inhibits prostate cell apoptosis except for the LP tissues at sulpiride $120 \mathrm{mg} / \mathrm{kg}$.

A previous study has determined that vimentin, an important intermediate fibrin protein in cells, functions as a general intermediate fiber and participates in the process of cell apoptosis (77). Morishima et al (78) revealed that apoptosis was accompanied by vimentin fragmentation. Fibronectin serves an important role in cell migration, adherence and proliferation. Wu et al (79) demonstrated that a lack of fibronectin triggers mesangial apoptosis via the intrinsic pathway. In the present study it was determined that sulpiride promotes the expression of stromal cell biomarkers vimentin and fibronectin in $\mathrm{BN}$ rats. Based on these results, it was hypothesized that sulpiride may inhibit the apoptosis of prostate cells by upregulating vimentin and fibronectin.

The aforementioned results of the current study indicate that sulpiride promotes proliferation and inhibits prostate cell apoptosis by upregulating PCNA, Bcl-2 and stromal cell biomarker (vimentin and fibronectin) expression.
The present study established a prostate hyperplasia model in $\mathrm{BN}$ rats treated with sulpiride $(40 \mathrm{mg} / \mathrm{kg} / \mathrm{day})$, the results of which indicate that sulpiride causes LP hyperplasia in $\mathrm{BN}$ rats by promoting proliferation and inhibiting apoptosis in prostate cells, likely via ER $\alpha$ and AR signaling. However, further study is required to fully elucidate the possible mechanisms by which sulpiride activates ER $\alpha$ and AR functions and the pathways involved.

\section{Acknowledgements}

Not applicable.

\section{Funding}

The present study was supported by the Shanghai Experimental Animal Scientific and Technological Innovative Action Plan (grant no. 17140900801) and the Shanghai Professional Service Platform of Non-clinical Evaluation of Drugs Against Women's and Children's Diseases (grant no. 17DZ2293600).

\section{Availability of data and materials}

The analyzed data sets generated during the present study are available from the corresponding author on reasonable request. 


\section{Authors' contributions}

ZS and YL designed the study. CZ performed the experiments and analyzed the experimental data. DC, CS, DH and JZ participated in the animal experiments. YC performed the ELISA experiments. XM and LL performed the tissue specimen preparation. All authors have read and approved this manuscript.

\section{Ethics approval and consent to participate}

The present study was approved by the Shanghai Institute of Planned Parenthood Research Animal Care (Shanghai, China). All animal procedures were approved by the Animal Care and Use Committee of Shanghai Institute of Planned Parenthood Research (Shanghai, China) and performed according to the Guide for the Care and Use of Laboratory Animals.

\section{Consent for publication}

Not applicable.

\section{Competing interests}

The authors declare that they have no competing interests.

\section{References}

1. Sampson N, Untergasser G, Plas E and Berger P: The ageing male reproductive tract. J Pathol 211: 206-218, 2007.

2. Afriyie DK, Asare GA, Bugyei K, Adjei S, Lin JM, Peng J and Hong ZF: Treatment of benign prostatic hyperplasia with Croton membranaceus in an experimental animal model. J Ethnopharmacol 157: 90-98, 2014.

3. Gratzke C, Schlenker B, Weidlich P, Seitz M, Reich O and Stief CG: Benign prostatic hyperplasia: Background and diagnosis. MMW Fortschr Med 149: 25-28, 2007 (In German).

4. Schauer IG and Rowley DR: The functional role of reactive stroma in benign prostatic hyperplasia. Differentiation 82: 200-210, 2011.

5. Akanni OO, Abiola OJ and Adaramoye OA: Methyl Jasmonate ameliorates testosterone propionate-induced prostatic hyperplasia in castrated wistar rats. Phytother Res 31: 647-656, 2017.

6. Kristiansen JE, Dastidar SG, Palchoudhuri S, Roy DS, Das S, Hendricks $\mathrm{O}$ and Christensen JB: Phenothiazines as a solution for multidrug resistant tuberculosis: From the origin to present. Int Microbiol 18: 1-12, 2015.

7. Martynova NA and Gorokhova LG: Toxicity assessment of sulpiride as the basis of its hygienic standardization. Gig Sanit 94: 114-117, 2015.

8. Van Coppenolle F, Slomianny C, Carpentier F, Le Bourhis X, Ahidouch A, Croix D, Legrand G, Dewailly E, Fournier S, Cousse $\mathrm{H}$, et al: Effects of hyperprolactinemia on rat prostate growth: Evidence of androgeno-dependence. Am J Physiol Endocrinol Metab 280: E120-E129, 2001.

9. Słuczanowska-Głąbowska S, Laszczyńska M, Wylot M, Głąbowski W, Piasecka M and Gącarzewicz D: Morphological and immunohistochemical comparison of three rat prostate lobes (lateral, dorsal and ventral) in experimental hyperprolactinemia. Folia Histochem Cytobiol 48: 447-454, 2010.

10. Payne MR, Howie PW, McNeilly AS, Cooper W, Marnie M and Kidd L: Sulpiride and the potentiation of progestogen only contraception. Br Med J (Clin Res Ed) 291: 559-561, 1985.

11. Farnsworth WE: Prolactin effect on the permeability of human benign hyperplastic prostate to testosterone. Prostate 12: 221-229, 1988.

12. Wolf K, Kayacelebi H, Urhausen C, Piechotta M, Mischke R, Kramer S, Einspanier A, Oei CH and Gunzel-Apel A: Testicular steroids, prolactin, relaxin and prostate gland markers in peripheral blood and seminal plasma of normal dogs and dogs with prostatic hyperplasia. Reprod Domest Anim 47 (Suppl 6): 243-246, 2012.
13. Drobnis EZ and Nangia AK: Psychotropics and male reproduction. Adv Exp Med Biol 1034: 63-101, 2017.

14. Zeng QS, Xu CL, Liu ZY, Wang HQ, Yang B, Xu WD, Jin TL, Wu CY, Huang G, Li Z, et al: Relationship between serum sex hormones levels and degree of benign prostate hyperplasia in Chinese aging men. Asian J Androl 14: 773-777, 2012.

15. Ahonen TJ, Härkönen PL, Rui H and Nevalainen MT: PRL signal transduction in the epithelial compartment of rat prostate maintained as long-term organ cultures in vitro. Endocrinology 143: 228-238, 2002 .

16. Thomas LN, Merrimen J, Bell DG, Rendon R and Too CK: Prolactin- and testosterone-induced carboxypeptidase-D correlates with increased nitrotyrosines and $\mathrm{Ki} 67$ in prostate cancer. Prostate 75: 1726-1736, 2015.

17. Pechenino AS and Brown TR: Superoxide dismutase in the prostate lobes of aging brown Norway rats. Prostate 66: 522-535, 2006.

18. Reiter E, Lardinois S, Klug M, Sente B, Hennuy B, Bruyninx M, Closset $\mathrm{J}$ and Hennen G: Androgen-independent effects of prolactin on the different lobes of the immature rat prostate. Mol Cell Endocrinol 112: 113-122, 1995.

19. Bole-Feysot C, Goffin V, Edery M, Binart N and Kelly PA: Prolactin (PRL) and its receptor: Actions, signal transduction pathways and phenotypes observed in PRL receptor knockout mice. Endocr Rev 19: 225-268, 1998.

20. Costello LC and Franklin RB: Effect of prolactin on the prostate. Prostate 24: 162-166, 1994.

21. Roehrborn CG: Pathology of benign prostatic hyperplasia. Int J Impot Res 20 (Suppl 3): S11-S18, 2008.

22. Porcaro AB, Migliorini F, Petrozziello A, Sava T, Romano M, Caruso B, Cocco C, Ghimenton C, Zecchinini AS, Lacola V, et al: Follicle-stimulating hormone and the pituitary-testicular-prostate axis at the time of initial diagnosis of prostate cancer and subsequent cluster selection of the patient population undergoing standard radical prostatectomy. Urol Int 90: 45-55, 2013.

23. Chowen-Breed J, Fraser HM, Vician L, Damassa DA, Clifton DK and Steiner RA: Testosterone regulation of proopiomelanocortin messenger ribonucleic acid in the arcuate nucleus of the male rat. Endocrinology 124: 1697-1702, 1989.

24. Rasmussen DD, Sarkar DK, Roberts JL and Gore AC: Chronic daily ethanol and withdrawal: 4 . Long-term changes in plasma testosterone regulation, but no effect on $\mathrm{GnRH}$ gene expression or plasma LH concentrations. Endocrine 22: 143-150, 2003.

25. Ottenweller JE, Li MT, Giglio W, Anesetti R, Pogach LM and Huang HF: Alteration of follicle-stimulating hormone and testosterone regulation of messenger ribonucleic acid for Sertoli cell proteins in the rat during the acute phase of spinal cord injury. Biol Reprod 63: 730-735, 2000.

26. Mattsson P and Medvedev A: Modeling of testosterone regulation by pulse-modulated feedback. Adv Exp Med Boil 823: 23-40, 2015.

27. Schanbacher BD: Testosterone regulation of luteinizing hormone and follicle stimulating hormone secretion in young male lambs. J Anim Sci 51: 679-684, 1980.

28. Alonso-Magdalena P, Brössner C, Reiner A, Cheng G, Sugiyama N, Warner M and Gustafsson JA: A role for epithelial-mesenchymal transition in the etiology of benign prostatic hyperplasia. Proc Natl Acad Sci USA 106: 2859-2863, 2009.

29. Shoieb SM, Esmat A, Khalifa AE and Abdel-Naim AB: Chrysin attenuates testosterone-induced benign prostate hyperplasia in rats. Food Chem Toxicol 111: 650-659, 2018.

30. Shi X, Peng Y, Du X, Liu H, Klocker H, Lin Q, Shi J and Zhang J: Estradiol promotes epithelial-to-mesenchymal transition in human benign prostatic epithelial cells. Prostate 77: 1424-1437, 2017.

31. Tsurusaki T, Aoki D, Kanetake H, Inoue S, Muramatsu M, Hishikawa Y and Koji T: Zone-dependent expression of estrogen receptors alpha and beta in human benign prostatic hyperplasia. J Clin Endocrinol Metab 88: 1333-1340, 2003.

32. Nicholson TM and Ricke WA: Androgens and estrogens in benign prostatic hyperplasia: Past, present and future. Differentiation 82: 184-199, 2011.

33. Song L, Shen W, Zhang H, Wang Q, Wang Y and Zhou Z: Differential expression of androgen, estrogen, and progesterone receptors in benign prostatic hyperplasia. Bosn J Basic Med Sci 16: 201-208, 2016 .

34. Choi HM, Jung Y, Park J, Kim HL, Youn DH, Kang J, Jeong MY, Lee JH, Yang WM, Lee SG, et al: Cinnamomi Cortex (Cinnamomum verum) suppresses testosterone-induced benign prostatic hyperplasia by regulating $5 \alpha$-reductase. Sci Rep 6: 31906, 2016. 
35. Roper WG: The prevention of benign prostatic hyperplasia (bph) Med Hypotheses 100: 4-9, 2017.

36. Luo Y, Waladali W, Li S, Zheng X, Hu L, Zheng H, Hu W and Chen C: 17beta-estradiol affects proliferation and apoptosis of rat prostatic smooth muscle cells by modulating cell cycle transition and related proteins. Cell Biol Int 32: 899-905, 2008.

37. Saito M, Tsounapi P, Oikawa R, Shimizu S, Honda M, Sejima T, Kinoshita Y and Tomita S: Prostatic ischemia induces ventral prostatic hyperplasia in the SHR; possible mechanism of development of BPH. Sci Rep 4: 3822, 2014.

38. Byun SS, Jeong H, Jo MK and Lee E: Relative proportions of tissue components in the prostate: Are they related to the development of symptomatic BPH in Korean men? Urology 66 : 593-596, 2005

39. Lean FZ, Kontos S and Palmieri C: Expression of $\beta$-catenin and mesenchymal markers in canine prostatic hyperplasia and carcinoma. J Comp Pathol 150: 373-381, 2014.

40. Wu JH, Jiang XR, Liu GM, Liu XY, He GL and Sun ZY: Oral exposure to low-dose bisphenol A aggravates testosterone-induced benign hyperplasia prostate in rats. Toxicol Ind Health 27: 810-819, 2011.

41. Shao R, Shi J, Liu H, Shi X, Du X, Klocker H, Lee C, Zhu Y and Zhang J: Epithelial-to-mesenchymal transition and estrogen receptor $\alpha$ mediated epithelial dedifferentiation mark the development of benign prostatic hyperplasia. Prostate 74: 970-982, 2014.

42. Sanchez P, Torres JM, Vilchez P, Del Moral RG and Ortega E: Effects of sulpiride on mRNA levels of steroid 5alpha-reductase isozymes in prostate of adult rats. Iubmb Life 60: 68-72, 2008.

43. Lee BH, Kang SG, Kim TW, Lee HJ, Yoon HK and Park YM Hyperprolactinemia induced by low-dosage amisulpride in Korean psychiatric patients. Psychiatry Clin Neurosci 66: 69-73, 2012.

44. Martinot JL, Paillère-Martinot ML, Poirier MF, Dao-Castellana MH, Loc'H C and Mazière B: In vivo characteristics of dopamine D2 receptor occupancy by amisulpride in schizophrenia. Psychopharmacology (Berl) 124: 154-158, 1996.

45. Abe Y, Yonemura K, Nishida K and Takagi K: Giant cell tumor of bone: Analysis of proliferative cells by double-labeling immunohistochemistry with anti-proliferating cell nuclear antigen antibody and culture procedure. Nihon Seikeigeka Gakkai Zasshi 68: 407-414, 1994.

46. Sun HB, Xia SJ and Tang XD: Expression of different genes in transitional zone and peripheral zone of human normal prostate. Zhonghua Yi Xue Za Zhi 85: 610-613, 2005 (In Chinese).

47. Liu YN, Abou-Kheir W, Yin JJ, Fang L, Hynes P, Casey O, Hu D, Wan Y, Seng V, Sheppard-Tillman H, et al: Critical and reciprocal regulation of KLF4 and SLUG in transforming growth factor $\beta$-initiated prostate cancerepithelial-mesenchymal transition. Mol Cell Biol 32: 941-953, 2012.

48. Shao R, Shi J, Liu H, Shi X, Du X, Klocker H, Lee C, Zhu Y and Zhang J: Epithelial-to-mesenchymal transition and estrogen receptor $\alpha$ mediated epithelial dedifferentiation mark the development of benign prostatic hyperplasi. Prostate 74: 970-982, 2014.

49. Sánchez P, Torres JM, Castro B, Frias JF and Ortega E: Effects of metoclopramide on mRNA levels of steroid $5 \alpha$-reductase isozymes in prostate of adult rats. J Physiol Biochem 69: 133-140, 2013.

50. Kindblom J, Dillner K, Ling C, Törnell J and Wennbo $\mathrm{H}$ : Progressive prostate hyperplasia in adult prolactin transgenic mice is not dependent on elevated serum androgen levels. Prostate 53: 24-33, 2002.

51. Wennbo H, Kindblom J, Isaksson OG and Törnell J: Transgenic mice overexpressing the prolactin gene develop dramatic enlargement of the prostate gland. Endocrinology 138: 4410-4415, 1997.

52. Rubin RT, Poland RE and Tower BB: Prolactin-related testosterone secretion in normal adult men. J Clin Endocrinol Metab 42: 112-116, 1976.

53. Rubin RT, Gouin PR, Lubin A, Poland RE and Pirke KM: Nocturnal increase of plasma testosterone in men: Relation to gonadotropins and prolactin. J Clin Endocrinol Metab 40: 1027-1033, 1975

54. Shen YC, Kang $\mathrm{CH}$ and Chiang PH: Efficacy of switching therapy of luteinizing hormone-releasing hormone analogue for advanced prostate cancer. Kaohsiung J Med Sci 32: 567-571, 2016.
55. Miki K, Sasaki H, Kido M, Takahashi H, Aoki M and Egawa S: A comparative study on the efficacies of gonadotropin-releasing hormone $(\mathrm{GnRH})$ agonist and $\mathrm{GnRH}$ antagonist in neoadjuvant androgen deprivation therapy combined with transperineal prostate brachytherapy for localized prostate cancer. BMC Cancer 16: 708, 2016.

56. Yamanaka H, Kosaku N, Makino T and Shida K: Fundamental and clinical study of the anti-prostatic effect of allylestrenol. Hinyokika Kiyo 29: 1133-1145, 1983 (In Japanese).

57. Liu RF, Fu G, Li J, Yang YF, Wang XG, Bai PD and Chen YD: Roles of autophagy in androgen-induced benign prostatic hyperplasia in castrated rats. Exp Ther Med 15: 2703-2710, 2018.

58. Hammond GL, Kontturi $M$, Määttälä $P$, Puukka $M$ and Vihko R: Serum FSH, LH and prolactin in normal males and patients with prostatic diseases. Clin Endocrinol (Oxf) 7: 129-135, 1977

59. Porcaro AB, Petrozziello A, Ghimenton C, Migliorini F, Sava T, Caruso B, Cocco C, Romano M and Artibani W: Along the pituitary-testis-prostate axis, serum total testosterone is a significant preoperative variable independently contributing to separating the prostate cancer population into prostatectomy Gleason score groups. Anticancer Res 32: 5015-5022, 2012.

60. Yuan ZF, Yang SC and Pan JT: Effects of prolactin-releasing peptide on tuberoinfundibular dopaminergic neuronal activity and prolactin secretion in estrogen-treated female rats: J Biomed Sci 9: 112-118, 2002.

61. Calogero AE, Weber RF, Raiti F, Burrello N, Moncada ML, Mongioi A and D'Agata R: Involvement of corticotropin-releasing hormone and endogenous opioid peptides in prolactin-suppressed gonadotropin-releasing hormone release in vitro. Neuroendocrinology 60: 291-296, 1994.

62. Ogura T, Tanaka Y, Tamaki H and Harada M: Docetaxel induces Bcl-2- and pro-apoptotic caspase-independent death of human prostate cancer DU145 cells. Int J Oncol 48: 2330-2338, 2016.

63. Ellem SJ and Risbridger GP: The dual, opposing roles of estrogen in the prostate. Ann N Y Acad Sci 1155: 174-186, 2009.

64. Weng YI, Hsu PY, Liyanarachchi S, Liu J, Deatherage DE, Huang YW, Zuo T, Rodriguez B, Lin $\mathrm{CH}$, Cheng AL and Huang TH: Epigenetic influences of low-dose bisphenol A in primary human breast epithelial cells. Toxicol Appl Pharmacol 248: 111-121, 2010.

65. Huang DY, Zheng CC, Pan Q, Wu SS, Su X, Li L, Wu JH and Sun ZY: Oral exposure of low-dose bisphenol A promotes proliferation of dorsolateral prostate and induces epithelial-mesenchymal transition in aged rats. Sci Rep 8: 490, 2018.

66. Banerjee PP, Banerjee S and Brown TR: Increased androgen receptor expression correlates with development of age-dependent, lobe-specific spontaneous hyperplasia of the brown Norway rat prostate. Endocrinology 142: 4066-4075, 2001.

67. Prins GS: Prolactin influence on cytosol and nuclear androgen receptors in the ventral, dorsal, and lateral lobes of the rat prostate. Endocrinology 120: 1457-1464, 1987.

68. Holland JM and Lee C: Effects of pituitary grafts on testosterone stimulated growth of rat prostate. Biol Reprod 22: 351-355, 1980.

69. Da J,Lu M and Wang Z: Estrogen receptor alpha (ER $\alpha$ )-associated fibroblasts promote cell growth in prostate cancer. Cell Biochem Biophys 73: 793-798, 2015.

70. Corradi LS, Jesus MM, Fochi RA, Vilamaior PS, Justulin LJ Jr, Góes RM, Felisbino SL and Taboga SR: Structural and ultrastructural evidence for telocytes in prostate stroma. J Cell Mol Med 17: 398-406, 2013.

71. Zhang S, Wu H and Liu C: Inhibition of lymphocyte proliferation: An ability shared by murine mesenchymal stem cells, dermal fibroblasts and chondrocytes. Transpl Immunol: Feb 20, 2018 (Epub ahead of print).

72. Van de Voorde WM, Elgamal AA, Van Poppel HP, Verbeken EK, Baert LV and Lauweryns JM: Morphologic and immunohistochemical changes in prostate cancer after preoperative hormonal therapy. A comparative study of radical prostatectomies. Cancer-Am Cancer Soc 74: 3164-3175, 1994.

73. Grant $\mathrm{CM}$ and Kyprianou N: Epithelial mesenchymal transition (EMT) in prostate growth and tumor progression. Transl Androl Urol 2: 202-211, 2013.

74. Hetzl AC, Montico F, Kido LA and Cagnon VH: Prolactin, EGFR, vimentin and $\alpha$-actin profiles in elderly rat prostate subjected to steroid hormonal imbalance. Tissue Cell 48: 189-196, 2016. 
75. Lindsay CR, Le Moulec S, Billiot F, Loriot Y, Ngo-Camus M Vielh P, Fizazi K, Massard C and Farace F: Vimentin and Ki67 expression in circulating tumour cells derived from castrate-resistant prostate cancer. BMC Cancer 16: 168, 2016.

76. Burch TC, Watson MT and Nyalwidhe JO: Variable metastatic potentials correlate with differential plectin and vimentin expression in syngeneic androgen independent prostate cancer cells. PLoS One 8: e65005, 2013

77. Haixuan Qiao, Qingming Wang and Huipeng Chen: Changes in vimentin during apoptosis. Bull Acad Military Med Sci: 275277 , 2005.
78. Morishima N: Changes in nuclear morphology during apoptosis correlate with vimentin cleavage by different caspases located either upstream or downstream of Bcl-2 action. Genes Cells 4: 401-414, 1999.

79. Wu D: Mechanism of apoptosis induced by knockdown of fbronectin in mesangial cells. (unpublished PhD thesis). General Hospital of PLA..

(i) () $\Theta$ This work is licensed under a Creative Commons Attribution-NonCommercial-NoDerivatives 4.0 International (CC BY-NC-ND 4.0) License. 